\title{
SISTEM PENGENDALIAN INTERN PADA KOPERASI SE-BALI
}

\author{
Ni Nyoman Ayu Suryandari ${ }^{1}$, Ni Luh Gde Novitasari² \\ Fakultas Ekonomi Universitas Mahasaraswati Denpasar \\ e-mail: a.suryandari@ymail.com
}

\begin{abstract}
Abstrak
Dalam perkembangannya ada berbagai permasalahan yang dihadapi koperasi, misalnya dalam pembiayaan dan permodalan. Agar mampu bersaing dengan lembaga keuangan lainnya, maka koperasi harus menentukan kebijakan dan strategi yang harus dikembangkan dan ditingkatkan. Salah satu kebijakan yang dapat diambil adalah meningkatkan efektivitas sistem pengendalian intern. Sistem pengendalian dalam koperasi diduga ditentukan oleh ukuran koperasi, jenis koperasi serta pengalaman kepengurusan dan manajemen. Penelitian pada koperasi jarang dilakukan karena koperasi sering dianggap sebagai organisasi kecil yang tidak begitu memerlukan pengendalian intern. Sampel yang digunakan dalam penelitian ini terdiri dari 98 koperasi dari 4.231 koperasi yang aktif di Bali dengan menyebarkan kuisioner pada koperasikoperasi tersebut. Penyebaran kuisioner dilakukan dengan teknik simple random sampling. Teknik analisis yang digunakan adalah regresi linear berganda. Hasil penelitian ini adalah ukuran koperasi berpengaruh positif terhadap kualitas sistem pengendalian intern, jenis koperasi berpengaruh terhadap kualitas sistem pengendalian intern, dan pengalaman kepengurusan dan manajemen tidak berpengaruh terhadap kualitas sistem pengendalian intern.
\end{abstract}

Kata kunci: ukuran, jenis, pengalaman kepengurusan koperasi

\begin{abstract}
In its development, there are various problems faced by cooperatives, such as in financing and capital. To be able to compete with other financial institutions, the cooperative must determine policies and strategies must be developed and improved. One of the policies that can be taken is to improve the effectiveness of the internal control system. The control systems in cooperative allegedly determined by the size of the cooperative, as well as the type cooperative stewardship and management experience. Cooperative research on rare because cooperatives are often regarded as small organizations that do not require internal control. The sample used in this study consisted of 98 cooperatives of 4,231 active cooperatives in Bali by distributing questionnaires on cooperatives. Distribution of questionnaires carried out by simple random sampling technique. The analysis technique used is multiple linear regression. The results of this study is a cooperative measure positive effect on the quality of internal control systems, the type cooperative effect on the quality of internal control systems, and experience management, and management does not affect the quality of the internal control system.
\end{abstract}

Keywords: size, type, cooperative management experience

\section{PENDAHULUAN}

Koperasi merupakan soko guru
perekonomian Indonesia.

permasalahan yang dihadapi oleh koperasi, misalnya dalam segi pembiayaan dan permodalan masih sulitnya koperasi mengakses lembaga keuangan (perbankan) mengingat syarat yang ditetapkan cukup berat terutama masalah jaminan atau agunan dan syarat lainnya. Persoalan seperti ini membuat banyaknya koperasi di Bali yang sudah 
tidak aktif beroperasi dan mengharuskan koperasi untuk dapat melakukan upaya demi menstabilkan dan lebih meningkatkan eksistensi usahanya.

Terdapat sekitar 465 koperasi yang tidak aktif di Bali. Agar mampu bersaing dengan lembaga keuangan lainnya, maka koperasi harus dapat menentukan suatu kebijakan dan strategi yang harus dikembangkan dan ditingkatkan. Salah satu kebijakan yang dapat diambil untuk membantu pengembangan koperasi adalah dengan meningkatkan efektivitas sistem pengendalian intern.

Sistem pengendalian dalam koperasi dapat dipengaruhi oleh beberapa faktor, misalnya ukuran koperasi, jenis koperasi serta pengalaman kepengurusan dan manajemen. Ukuran koperasi dapat dilihat dari jumlah omzet pertahunnya. Koperasi besar memiliki kemungkinan yang besar untuk menerapkan sistem pengendalian intern yang lebih baik daripada koperasi yang berukuran kecil. Faktor lain yang dapat memengaruhi sistem pengendalian intern pada koperasi yaitu jenis koperasinya. Tiap-tiap jenis koperasi dapat membedakan cara pengawasan/pengendalian internnya.

Faktor pengalaman kepengurusan dan manajemen koperasi dapat dilihat dari lama waktu/masa kerja yang dimiliki oleh kepengurusan dan manajemen koperasi. Semakin berpengalaman kepengurusan dan manajemen maka akan dapat menghindari kecurangan yang dapat merugikan koperasi.

Penelitian tentang pengendalian intern pada koperasi belum banyak diteliti. Tidak seperti biasanya yang kebanyakan penelitian tentang pengendalian intern dilakukan di BUMN/D atau perusahaan manu faktur. Penelitian pada koperasi jarang dilakukan karena koperasi sering dianggap sebagai organisasi kecil yang tidak begitu memerlukan pengendalian intern.

Berdasarkan uraian latar belakang di atas, maka rumusan masalah dalam penelitian ini adalah Apakah ukuran koperasi, jenis koperasi serta pengalaman kepengurusan dan manajemen berpengaruh terhadap kualitas sistem pengendalian intern pada koperasikoperasi di Bali.

Menurut Jensen dan Meckling (1976), teori agensi (agency theory) merupakan konsep yang menjelaskan hubungan kontraktual antara principals dan agents. Berdasarkan teori keagenan tersebut maka sistem pengendalian intern dirasa sangat penting bagi sebuah organisasi untuk menghindari konflik kepentingan yang terjadi antara principal dan agen. Sistem pengendalian intern berfungsi untuk mengawasi tugas dan fungsi masing-masing unit bagian sehingga setiap unit bagian memiliki tugas dan wewenang masing-masing.

Menurut Undang-Undang Nomor 17 Tahun 2012 tentang Perkoperasian, koperasi adalah badan hukum yang didirikan oleh orang perseorangan atau badan hukum koperasi, dengan pemisahan kekayaan para anggotanya sebagai modal untuk menjalankan usaha, yang memenuhi aspirasi dan kebutuhan bersama di bidang ekonomi, sosial dan budaya sesuai dengan nilai prinsip koperasi.

\begin{tabular}{ccc} 
Berdasarkan & \multicolumn{2}{c}{ Undang-Undang } \\
Nomor 17 Tahun 2012 tentang
\end{tabular}
Perkoperasian jenis koperasi terdiri dari empat jenis koperasi, yaitu: pertama koperasi konsumen. Koperasi konsumen adalah koperasi yang menyelenggarakan kegiatan usaha pelayanan di bidang penyediaan barang kebutuhan anggota dan non anggota. Koperasi produsen. Koperasi produsen adalah koperasi yang menyelenggarakan kegiatan usaha pelayanan di bidang pengadaan sarana produksi dan pemasaran produksi yang dihasilkan anggota kepada anggota dan non anggota. ketiga koperasi Jasa. Koperasi jasa adalah koperasi yang menyelenggarakan kegiatan usaha pelayanan jasa non-simpan pinjam yang diperlukan oleh anggota dan non-anggota. Keempat koperasi Simpan Pinjam. Koperasi simpan pinjam adalah koperasi yang menjalankan usaha simpan pinjam sebagai salah satunya usaha yang melayani anggota.

Undang-Undang Nomor 17 tentang Perkoperasian dibatalkan pada hari Rabu, 28 Mei 2014 oleh Mahkamah Konsitusi dan kembali ke Undang-Undang 
Nomor 25 Tahun 1992 tentang Perkoperasian. Dalam Undang-Undang Republik Indonesia Nomor 25 Tahun 1992 tentang Perkoperasian jenis koperasi dibedakan menjadi lima, yaitu: Koperasi Simpan Pinjam, Koperasi Konsumen, Koperasi Produsen, Koperasi Jasa, dan Koperasi Pemasaran (koperasi yang menjalankan kegiatan penjualan produk/jasa koperasi atau anggotanya)

Pengaruh Ukuran Koperasi Terhadap Kualitas Sistem Pengendalian Intern Ukuran koperasi dalam penelitian ini diklasifikasikan menjadi tiga yaitu koperasi berukuran besar, menengah dan kecil berdasarkan omzet (volume usaha) per tahunnya. Semakin besar ukuran koperasi mencerminkan bahwa usaha yang dikelola koperasi semakin besar. Semakin besar koperasi, semakin kompleks transaksinya maka semakin sulit dalam mengawasi kegiatan usahanya.

Dengan semakin besarnya ukuran koperasi maka kualitas sistem pengendalian intern umum, penerimaan kas, pengeluaran kas, dan praktik rekonsiliasi yang digunakan juga harus semakin baik dan terkontrol (Palupi, 2011). Besarnya usaha koperasi dapat berpotensi menimbulkan permasalahan yang semakin kompeks. Untuk memecahkan masalah yang timbul akibat kompleksnya transaksi yang ada sangat dibutuhkan sistem pengendalian intern. Semakin besar koperasi maka sangat diperlukan kualitas sistem pengendalian intern yang lebih baik (Palupi, 2011).

Hasil penelitian yang dilakukan oleh Palupi (2011) menunjukkan bahwa ukuran tidak berpengaruh signifikan terhadap kualitas sistem pengendalian intern. Hasil penelitian ini tidak memperoleh adanya perbedaan aspekaspek pengendalian yang digunakan oleh koperasi kecil, koperasi menengah maupun koperasi besar. Sedangkan hasil penelitian Hasmawati (2012) menunjukkan bahwa adanya perbedaan kualitas sistem pengendalian intern dari ukuran koperasi sehingga dapat dikatakan bahwa kualitas sistem pengendalian intern yang diterapkan oleh koperasi yang berukuran kecil, menengah maupun besar berbeda. Semakin besar modal, omzet dan asset koperasi maka sistem pengendalian internnya semakin baik.

Dengan kata lain menunjukkan bahwa ukuran koperasi mempengaruhi kualitas sistem pengendalian intern koperasi. Dari penjelasan tersebut, maka hipotesis yang digunakan dalam penelitian ini adalah: $\mathrm{H}_{1}$ :Ukuran koperasi berpengaruh positif terhadap kualitas sistem pengendalian intern.

Pengendalian kredit merupakan bagian dari pengendalian intern yang bertujuan untuk menjaga agar kredit yang diberikan tetap lancar, produktif dan tidak macet. Lancar dan produktif artinya kredit itu dapat ditarik kembali bersama bunganya sesuai dengan perjanjian yang telah disetujui kedua belah pihak (Baridwan, 2002). Pengendalian kredit penting, sebab jika terjadi kredit macet berarti bagi bank bersangkutan akan menderitakerugian, oleh karena itu penyaluran kredit harus didasarkan pada prinsip kehati-hatian dan dengan sistem pengendalian kredit yang baik dan benar.

Pengendalian kredit adalah usahausaha untuk menjaga kredit agar tetap lancar, produktif, dan tidak macet. Lancar dan produktif artinya kredit itu dapat ditarik kembali bersama bunganya sesuai dengan perjanjian yang telah disetujui kedua belah pihak. Pemberian kredit harus didasarkan pada prinsip kehatihatian dan dengan sistem pengendalian yang baik dan benar" (Hasibuan, 2005). Pendapat lain, "pengendalian intern terhadap pemberian kredit terdiri atas aspek pengendalian intern kredit, proses aktivitas pengendalian kredit, serta unsurunsur pegendalian intern kredit" (Tawaf, 1999). Tujuan "Pengendalian intern" adalah untuk memastikan bahwa KJK menerima seluruh pendapatannya tanpa ada yang hilang akibat pemborosan, penipuan, karyawan yang tidak jujur, atau hanya karena kesembronoan. Bahkan sebuah KJK yang sehat dalam segala aspek dapat sangat rentan terhadap kegagalan dari dalam karena kurangnya pengendalian intern (Kuncoro, 2002).

Menurut UU No, 10 Tahun 1998 menyebutkan bahwa Peraturan-peratura untuk melaksanakan pengendalian intern pada Koperasi adalah : satu Undangundang nomor 25 Tahun 1992 tentang 
perkoperasian. Dua PP. Nomor 9 Tahun 1995 tentang Pelaksanaan kegiatan usaha simpan pinjam oleh koperasi. Tiga Keputusan Menteri Koperasi dan PKM nomor 351/Kep/M/XII/1998 tentang Petunjuk pelaksanaan kegiatan usaha simpan pinjam oleh koperasi. Empat Keputusan Menteri Koperasi dan UKM nomor 91/Kep/M.KUKM/IX/2004 tentang Petunjuk pelaksanaan kegiatan usaha Koperasi Jasa Keuangan Syariah. Lima Keputusan Menteri Koperasi dan UKM nomor 96/Kep/M.KUKM/IX/2004 tentang Pedoman Standar Operasional Manajemen Koperasi Simpan Pinjam dan Unit Simpan Pinjam Koperasi. Enam Anggaran Dasar, Anggaran Rumah Tangga dan ketentuan khusus lain yang berlaku di masing-masing KJK

Pengaruh Jenis Koperasi Terhadap Kualitas Sistem Pengendalian Intern Koperasi Berdasarkan Undang-Undang Republik Indonesia Nomor 17 Tahun 2012 tentang Perkoperasian, jenis-jenis koperasi dibedakan menjadi empat, yaitu koperasi konsumen, koperasi produsen, koperasi jasa dan koperasi simpan pinjam. Jenis koperasi tersebut didasarkan pada kesamaan aktivitas, kepentingan dan kebutuhan ekonomi anggotanya. Berdasarkan perbedaan tersebut maka tiap-tiap koperasi membutuhkan cara pengawasan atau sistem pengendalian intern yang berbeda. Palupi (2011) dan Hasmawati (2012) menyatakan bahwa jenis koperasi berpengaruh terhadap kualitas sistem pengendalian intern. Dari penjelasan tersebut, maka hipotesis yang digunakan dalam penelitian ini adalah: $\mathrm{H}_{2}$ :Jenis koperasi berpengaruh terhadap kualitas sistem pengendalian intern.

Pengaruh

Pengalaman Kepengurusan dan manajemen Terhadap Kualitas Sistem Pengendalian Intern Koperasi. Pengalaman kepengurusan dan manajemen koperasi indikatornya dapat dilihat dari pengalaman mengelola organisasi dan usaha koperasi yaitu lama waktu/masa kerja kepengurusan dan manajemen dalam menentukan sistem pengendalian intern. Hasil penelitian yang dilakukan oleh Rinawati (2007) menunjukkan bahwa pengalaman pengurus berpengaruh positif terhadap keberhasilan usaha koperasi baik secara langsung maupun tidak langsung.

Husnan (2010) juga menunjukkan bahwa pengalaman kerja berpengaruh terhadap efektivitas penerapan sistem pengendalian internnya. Ini dikarenakan semakin berpengalaman maka akan lebih mampu bekerja lebih teliti dan mampu mengetahui penyimpanganpenyimpangan yang terjadi dengan cepat dan disiplin waktu serta semakin berpengalaman maka semakin mampu menghasilkan kinerja yang lebih baik dalam tugas-tugasnya yang semakin kompleks, termasuk dalam melakukan pengawasan dan pemeriksaan terhadap penerapan struktur pengendalian intern koperasi. Dari penjelasan tersebut, maka hipotesis yang digunakan dalam penelitian ini adalah: $\mathrm{H}_{3}$ :Pengalaman

kepengurusan dan manajemen berpengaruh positif terhadap kualitas sistem pengendalian intern

\section{METODE PENELITIAN}

Jenis data yang digunakan dalam penelitian ini adalah data kualitatif dan kuantitatif. Sedangkan sumber data dalam penelitian ini dibagi dalam 2 jenis yaitu sumber data primer dan data sekunder. Variabel dalam penelitian ini dibagi menjadi 2 yaitu variabel dependen dan independen. Pertama Variabel dependen dalam penelitian ini adalah kualitas sistem pengendalian intern. Kuisioner tersebut terdiri dari empat unsur pertanyaan tentang sistem pengendalian intern, yaitu sistem pengendalian untuk umum, sistem pengendalian penerimaan kas, sistem pengendalian pengeluaran kas, dan sistem pengendalian untuk praktik rekonsiliasi.

Kuisioner sistem pengendalian intern diadopsi dari Fidaus (2006), Rustandhi (2004), Ulfa (2011) dan Binus (2007). Kedua variabel independen. Dalam penelitian ini, yang menjadi variabel independen atau variabel bebas adalah: pertama ukuran koperasi yang dimaksud adalah besar kecilnya koperasi berdasarkan omzet (volume usaha) dalam laporan perkembangan usaha selama setahun. Variabel ukuran koperasi 
merupakan variabel dummy dimana untuk koperasi berukuran besar (omzet diatas satu miliar) diberi nilai 3 (tiga), koperasi menengah (omzet antara lima ratus juta sampai satu miliar) diberi nilai 2 (dua) dan koperasi berukuran kecil (omzet kurang dari lima ratus juta) diberi nilai 1 (satu). Kedua jenis Koperasi. Jenis koperasi terdiri dari empat yaitu koperasi konsumen, koperasi produsen, koperasi jasa dan koperasi simpan pinjam. Variabel jenis koperasi merupakan variabel dummy dimana untuk koperasi konsumen diberi nilai 1 (satu), koperasi produsen diberi nilai 2 (dua), koperasi jasa diberi nilai 3 (tiga) dan koperasi simpan pinjam diberi nilai 4 (empat). Ketiga pengalaman Kepengurusan dan manajemen. engalaman kepengurusan dan manajemen ditentukan dari lama waktu/masa kerja kepengurusan dan manajemen. Penilaian untuk lama waktu/masa kerja yaitu antara nilai 1 sampai 3 , yaitu masa kerja $0-5$ tahun diberi nilai 1 (satu), masa kerja di atas 510 tahun diberi nilai 2 (dua) dan masa kerja di atas 10 tahun diberi nilai 3 (tiga).

Populasi dalam penelitian ini adalah koperasi-koperasi yang terdapat di
Bali. Total koperasi yang terdapat di Bali adalah 4.696. Sedangkan sampel dalam penelitian ini adalah koperasi-koperasi yang masih aktif beroperasi di Bali. Jumlah koperasi aktif yang terdapat di Bali sejumlah 4.231. Dalam penelitian ini digunakan rumus slovin untuk menentukan jumlah sampel dengan hasil sampel sebanyak 98.

Responden yang mengisi kuisioner adalah manajer atau kepala operasional atau pengurus dari tiap-tiap koperasi. Dan satu koperasi diberi satu kuisioner. Penyebaran kuisioner dilakukan dengan teknik simple random sampling. Metode yang digunakan dalam penelitian ini yaitu kuesioner dan dokumentasi. Teknik analisis data yang digunakan dalam penelitian ini adalah analisis regresi linear berganda.

\section{HASIL DAN PEMBAHASAN}

Berikut ini adalah tabel jumlah pengambilan sampel koperasi yang dikirimkan, jumlah kembali dan sampel yang digunakan untuk penelitian, yaitu dapat dilihat pada tabel 1 .

Tabel 1. Jumlah Sampel Koperasi

\begin{tabular}{lcccc}
\hline $\begin{array}{c}\text { Kabupaten/Kota } \\
\text { Madya }\end{array}$ & $\begin{array}{c}\text { Jumlah Kuesioner } \\
\text { Dikirim }\end{array}$ & $\begin{array}{c}\text { Jumlah Kuesioner } \\
\text { Kembali }\end{array}$ & $\begin{array}{c}\text { Jumlah Kuesioner } \\
\text { Digunakan }\end{array}$ & Presentase \\
\hline Denpasar & 33 & 33 & 33 & $33,68 \%$ \\
Badung & 14 & 14 & 14 & $14,29 \%$ \\
Tabanan & 9 & 9 & 9 & $9,18 \%$ \\
Gianyar & 7 & 7 & 7 & $7,14 \%$ \\
Bangli & 13 & 13 & 13 & $13,27 \%$ \\
Buleleng & 9 & 9 & 9 & $9,18 \%$ \\
Klungkung & 5 & 5 & 5 & $5,10 \%$ \\
Karangasem & 5 & 5 & 5 & $5,10 \%$ \\
Jembrana & 3 & 3 & 3 & $3,06 \%$ \\
\multicolumn{1}{c}{ TOTAL } & 98 & 98 & 98 & $100 \%$ \\
\hline
\end{tabular}

Sedangkan prosentase sampel per Sumber: data diolah (2016) masing-masing kabupaten adalah sebagai berikut: 
Tabel 2. Jumlah Sampel Koperasi

Kabupaten/Kota Madya Jumlah Koperasi Aktif Jumlah Sampel Prosentase

\begin{tabular}{lccc}
\hline Denpasar & 1.017 & 33 & $3,24 \%$ \\
Badung & 455 & 14 & $3,08 \%$ \\
Tabanan & 495 & 9 & $1,8 \%$ \\
Gianyar & 1.047 & 7 & $0,67 \%$ \\
Bangli & 217 & 13 & $5,99 \%$ \\
Buleleng & 350 & 9 & $2,57 \%$ \\
Klungkung & 119 & 5 & $4,20 \%$ \\
Karangasem & 295 & 5 & $1,69 \%$ \\
Jembrana & 236 & 3 & $1,27 \%$ \\
\multicolumn{1}{c}{ TOTAL } & 4.231 & \multicolumn{3}{c}{ Sumber. data diolah $(2016)$}
\end{tabular}

Berdasarkan hasil uji normalitas Kolmogorov Smirnov Test menunjukan Sig. (2-tailed) 0,114 yang lebih besar dari level of significant 0,05 , sehingga dapat disimpulkan bahwa residual berdistribusi normal.

Berdasarkan hasil pengujian multikolonieritas diketahui bahwa tidak ada multikolonieritas antar variabel bebas (independent) dalam model regresi. Berdasarkan hasil pengujian heteroskedastisitas menunjukkan nilai signifikansi masing-masing variabel bebas lebih dari 0,05 sehingga dapat disimpulkan bahwa model regresi dalam penelitian ini bebas dari heteroskedastisitas. Hasil pengujian Adjusted $R$ Square diperoleh sebesar 0,393 artinya sebesar 39,3 persen variasi dari variabel dependen (kualitas sistem pengendalian intern) mampu dijelaskan oleh variabel independen (ukuran koperasi, jenis koperasi, pengalaman kepengurusan dan manajemen), sedangkan sisanya 60,7 persen dijelaskan oleh variabel lain diluar penelitian ini.

Berdasarkan hasil pengujian secara serempak pada Tabel 3.7 diperoleh hasil $F_{\text {hitung }} 21,969$ dengan signifikansi 0,000 lebih kecil dari 0,05. Hasil ini menunjukkan bahwa ukuran koperasi, jenis koperasi serta pengalaman kepengurusan dan manajemen secara bersama-sama berpengaruh terhadap kualitas sistem pengendalian intern. Pengujian yang dilakukan secara parsial terhadap parameter dilakukan dengan menggunakan uji t ( $t$-test).

Tabel 3. Hasil Analisis Uji Statistik t

\begin{tabular}{llrrrr}
\hline & \multicolumn{2}{c}{ Unstandardized } & \multicolumn{2}{c}{$\begin{array}{c}\text { Standardized } \\
\text { Coefficients }\end{array}$} & \multicolumn{2}{c}{ Coeffisients } \\
& Model & Beta & t & Sig \\
\hline 1 (Constant) & 9,122 & 2,876 & & 3,172 & 0,002 \\
X $_{1}$ & 3,841 & 0,994 & 0,323 & 3,865 & 0,000 \\
X $_{2}$ & 3,469 & 0,630 & 0,448 & 5,509 & 0,000 \\
$X_{3}$ & 1,917 & 1,098 & 0,142 & 1,745 & 0,084 \\
\hline
\end{tabular}

Sumber. data diolah (2016)

Berdasarkan tabel 3 diatas dapat diperoleh hasil sebagai berikut:pertama ukuran koperasi berpengaruh positif terhadap kualitas sistem pengendalian intern yang diterapkan pada koperasikoperasi di Bali sehingga hipotesis pertama dalam penelitian ini diterima. Kedua jenis koperasi berpengaruh 
terhadap kualitas sistem pengendalian intern yang diterapkan pada koperasikoperasi di Bali sehingga hipotesis kedua dalam penelitian diterima. Ketiga pengalaman kepengurusan dan manajemen tidak berpengaruh terhadap kualitas sistem pengendalian intern yang diterapkan pada koperasi-koperasi di Bali sehingga hipotesis ketiga dalam penelitian ini ditolak. Hasil analisis deskriptif dari variabel-variabel penelitian ini disajikan pada Tabel 4.4 berikut ini:

Tabel 4. Statistik Deskriptif

\begin{tabular}{lccccc}
\hline & $\mathrm{N}$ & Minimum & Maximum & Mean & $\begin{array}{c}\text { Std. } \\
\text { Deviation }\end{array}$ \\
\hline $\mathrm{Y}$ & 98 & 4,00 & 43,00 & 30,5714 & 10,07600 \\
$\mathrm{X}_{1}$ & 98 & 1,00 & 3,00 & 1,9388 & 0,84727 \\
$\mathrm{X}_{2}$ & 98 & 1,00 & 4,00 & 3,1735 & 1,30048 \\
$\mathrm{X}_{3}$ & 98 & 1,00 & 3,00 & 1,5612 & 0,74704 \\
Valid N (listwise) & & & & & \\
\hline
\end{tabular}

Sumber. data diolah (2016)

Hasil uji analisis linear berganda disajikan pada Tabel 5 berikut ini

Tabel 5 Hasil Analisis Regresi Linear Berganda

\begin{tabular}{|c|c|c|c|c|c|}
\hline \multirow[b]{2}{*}{ Model } & \multicolumn{2}{|c|}{$\begin{array}{l}\text { Unstandardized } \\
\text { Coefficients }\end{array}$} & \multirow{2}{*}{$\begin{array}{c}\text { Standardized } \\
\text { Coeffisients } \\
\text { Beta }\end{array}$} & \multirow[b]{2}{*}{$t$} & \multirow[b]{2}{*}{ Sig } \\
\hline & $\mathrm{B}$ & Std. Error & & & \\
\hline 1 (Constant) & 9,122 & 2,876 & & 3,172 & 0,002 \\
\hline $\mathrm{X}_{1}$ & 3,841 & 0,994 & 0,323 & 3,865 & 0,000 \\
\hline$x_{2}$ & 3,469 & 0,630 & 0,448 & 5,509 & 0,000 \\
\hline$x_{3}$ & 1,917 & 1,098 & 0,142 & 1,745 & 0,084 \\
\hline
\end{tabular}

Sumber. data diolah (2016)

Pengaruh ukuran koperasi
terhadap pengendalian intern. Hipotesis pertama dalam penelitian ini adalah ukuran koperasi berpengaruh positif terhadap kualitas sistem pengendalian intern. Hasil pengujian hipotesis menunjukkan bahwa ukuran koperasi berpengaruh positif terhadap kualitas sistem pengendalian intern yang ditunjukkan dengan koefisien regresi sebesar 3,841 dan nilai signifikansi sebesar 0,000 dimana signifikansi lebih kecil dari 0,05. Dengan demikian semakin besar ukuran koperasi maka kualitas sistem pengendalian intern yang digunakan akan semakin baik dan terkontrol. Hasil pengujian dalam penelitian ini membuktikan adanya perbedaan aspek-aspek pengendalian yang digunakan oleh koperasi berukuran besar, koperasi berukuran menengah dan koperasi berukuran kecil. Adanya perbedaan yang signifikan pada umumnya didukung oleh adanya penerapan sistem pengendalian intern (SPI) umum, penerimaan kas, pengeluaran kas dan praktik rekonsiliasi yang berbeda pada koperasi besar, koperasi menengah dan koperasi kecil, sehingga dapat dikatakan bahwa kualitas sistem pengendalian intern yang diterapkan koperasi berukuran kecil, menengah maupun besar berbeda.

Hasil penelitian ini konsisten dengan penelitian Hasmawati (2012) yang menyatakan bahwa ukuran koperasi berpengaruh positif terhadap kualitas sistem pengendalian intern. Hasil penelitian ini tidak konsisten dengan penelitian Palupi (2011) yang menunjukan bahwa ukuran koperasi tidak berpengaruh terhadap kualitas sistem pengendalian intern. 
Pengaruh Jenis Koperasi terhadap Kualitas Sistem Pengendalian Intern. Hipotesis kedua dalam penelitian ini adalah jenis koperasi berpengaruh terhadap kualitas sistem pengendalian intern. Hasil pengujian hipotesis menunjukkan bahwa jenis koperasi berpengaruh terhadap kualitas sistem pengendalian intern yang ditunjukkan dengan nilai koefisien regresi sebesar 3,469 dan nilai signifikansi sebesar 0,000 dimana signifikansi lebih kecil dari 0,05.

Berdasarkan hasil pengujian dalam penelitian ini menunjukkan adanya perbedaan kualitas sistem pengendalian intern baik umum, penerimaan kas, pengeluaran kas dan praktik rekonsiliasi dilihat dari jenis usaha koperasi. Sehingga dapat dikatakan bahwa kualitas sistem pengendalian intern yang diterapkan oleh koperasi konsumen, koperasi produsen, koperasi jasa dan koperasi simpan pinjam adalah berbeda. Jenis koperasi didasarkan pada kesamaan kegiatan usaha dan/atau kepentingan ekonomi anggotanya. Berdasarkan perbedaan tersebut maka tiap-tiap koperasi membutuhkan cara pengawasan atau sistem pengendalian intern yang berbeda. Dengan kata lain jenis koperasi mampu mempengaruhi kualitas sistem pengendalian internnya.

Hasil penelitian ini tidak konsisten dengan hasil penelitian Palupi (2011) dan Hasmawati (2012) yang menyatakan bahwa ukuran koperasi tidak berpengaruh signifikan terhadap kualitas sistem pengendalian intern.

\section{Pengaruh}

pengalaman

kepengurusan dan manajemen terhadap kualitas sistem pengendalian Intern. Hipotesis ketiga dalam penelitian ini adalah pengalaman kepengurusan dan manajemen berpengaruh positif terhadap kualitas sistem pengendalian intern. Hasil pengujian hipotesis menunjukkan bahwa pengalaman kepengurusan dan manajemen tidak berpengaruh terhadap kualitas sistem pengendalian intern yang ditunjukkan koefisien regresi sebesar 1,917 dan nilai signifikansi sebesar 0,085 dimana signifikansi lebih besar dari 0,05.

Hal tersebut menunjukkan bahwa lamanya kepengurusan dan manajemen pada koperasi tempatnya bekerja tidak berpengaruh terhadap efektivitas penerapan sistem pengendalian intern. Hal ini mungkin lebih disebabkan oleh faktor lain seperti pengalaman bekerja ditempat lain, pendidikan dan gaya kepemimpinan. Hasil penelitian ini tidak konsisten dengan penelitian Husnan (2010) dan Rinawati (2007) yang menunjukkan bahwa pengalaman kerja (pengalaman kepengurusan) berpengaruh terhadap efektivitas penerapan sistem pengendalian intern.

\section{SIMPULAN DAN SARAN}

Berdasarkan hasil analisis data, pengujian hipotesis dan pembahasan, maka dapat disimpulkan sebagai berikut: pertama variabel ukuran koperasi berpengaruh positif terhadap kualitas sistem pengendalian intern. Ini berarti bahwa semakin besar koperasi maka kualitas sistem pengendalian internnya akan semakin baik. Kedua variabel jenis koperasi berpengaruh terhadap kualitas sistem pengendalian intern. Adanya perbedaan kualitas sistem pengendalian intern yang diterapkan oleh koperasi konsumen, koperasi jasa, dan mempengaruhi kualitas sistem pengendalian intern. Ketiga variabel kepengurusan dan manajemen tidak berpengaruh terhadap kualitas sistem pengendalian intern. Hal ini mungkin lebih dipengaruhi oleh faktor pengalaman bekerja sebelumnya, pendidikan dan gaya kepemimpinan.

Saran yang diberikan kepada: pertama penelitian selanjutnya disarankan untuk dapat mengembangkan faktorfaktor yang dapat digunakan sebagai alat ukur kualitas sistem pengendalian intern koperasi. Kedua penelitian selanjutnya disarankan untuk dapat menggunakan teknik penentuan sampel yang berbeda sehingga dapat lebih mudah dan tepat dalam menentukan sampel yang akan diberikan.

\section{DAFTAR PUSTAKA}

Baridwan, Zaki. 2002. Sistem Akuntansi Penyusunan Prosedur dan Metode. Yogyakarta: BPFE Yogyakarta 
Djohan, Djabarudin. 2011. "Wajah Koperasi Indonesia". Jakarta: Lembaga Studi Pengembangan Perkoperasian Indonesia (LSP2I). Induk Koperasi Kredit (Inkopdit).

Ghozali, Imam. 2012. "Aplikasi Analisis Multivariate dengan Program SPSS 20". Semarang: Badan Penerbit Universitas Diponegoro.

Halim, Abdul dan Santoso, Totok Budi. 2005. "Auditing 2, Dasar-dasar Prosedur Pengauditan Laporan Keuangan". Edisi Ketiga. Yogyakarta: Akademi Manajemen Perusahaan YKPN.

Hasibuan, Malayu. 2005. Dasar-dasar Perbankan. Jakarta: Bumi Aksara

Hasmawati, Novrina. 2012. "Pengaruh Ukuran Koperasi dan Jenis Koperasi Terhadap Kualitas Sistem Pengendalian Intern". Diponegoro Journal of Accounting Volume 1, Nomor 2, Tahun 2012, Universitas Diponegoro. http:ejournal-

sl.undip.ac.id/index.php/accounting - Diakses pada tanggal 05 Nopember 2013.

Himpunan Peraturan Tentang Perbankan, Perkoperasian, Usaha Mikro, Kecil dan Menengah, Jakarta: PT.Tamita Utama.

Jusuf, Haryono, Al. 2001. Auditing Cetakan Pertama. Yogyakarta: Sekolah Tinggi Ilmu Ekonomi YKPN.

Komala, Yuniarta, dan Adiputra. 2014. Analisis Perbedaan Ukuran Koperasi dan Jenis Koperasi Terhadap Kualitas Sistem Pengendalian Intern (Studi Kasus Pada Koperasi di Kabupaten Buleleng). Jimat. Universitas Pendidikan Ganesha

Kuncoro, Mundrajad dan Suhardjono. 2002. Manajemen Perbankan Teori dan Aplikasi. Yogyakarta dan Makassar: BPFE

Mulyadi, 2002. Auditing I Edisi 6. Jakarta: Salemba Empat.

Palupi, Astri Ken. 2011. "Pengaruh Ukuran Koperasi dan Jenis Koperasi Terhadap Kualitas Sistem Pengendalian Intern". Skripsi. Univeristas Diponegoro, diakses pada tanggal 05 Nopember 2013.

Republik Indonesia. Undang-Undang Republik Indonesia Nomor 17 Tahun 2012 tentang Perkoperasian. Sinar Grafika.

Republik Indonesia. Undang-Undang Republik Indonesia Nomor 25 Tahun 1992 tentang Perkoperasian.

Rinawati, Anita. 2007. "Pengaruh Pendidikan Perkoperasian Anggota, Permodalan dan Pengalaman Pengurus Terhadap Keberhasilan Usaha Koperasi". Universitas Muhammadiyah Purworejo, ejournal.impwr.ac.id. diakses pada tanggal 15 Nopember 2013

Rustandhi, Hana Fatmawati. 2004. "Pengaruh Pengendalian Intern Kas Terhadap Realisasi Pencatatan Penerimaan Kas". Jurnal. UNIKOM. http://www.slideshare.net/myselv/k uisioner-pengendalian-intern diakses pada tanggal 04 Januari 2014.

Sudarsono, Edilius. 2005. "Koperasi Dalam Teori dan Praktek". Jakarta: Rineka Cipta.

Sugiyono. 2013. "Metode Penelitian Bisnis" Cetakan ke-17. Bandung: CV. Alfabeta.

Sumarna.2013."Pengaruh Sistem Pengendalian Intern Terhadap Keberhasilan Usaha Koperasi di Tanjungpinang". Skripsi. Universitas Maritim Raja Ali Haji.

Tawaf, Tjukra P. 1999. Audit Intern Bank Buku Satu. Jakarta: Salemba Empat

Ulfa, Umi Maria. 2011. "Evaluasi Sistem Pengendalian Intern Pengeluaran Kas PT. Global Engineering Technology Jakarta".Universitas Diponegoro.

http://eprints.undip.ac.id/26466.

diakses pada tanggal 14 Januari 2014.

Undang-undang No. 10 tahun 1998 tentang Perbankan. Jakarta: Asa Mandiri 